\section{A New Approach to School Mathematics}

Writh the re-classification of secondary schools in Great Britain under the new Education Act, there is an urgent need for the complete overhaul of the curricula of these schools. This is especially true in the case of mathematics, evidence of which is to be found in the recent reports on school certificate mathematies (Conf. Exam. Bodies and Teachers' Associations, 1944); on the teaching of mathematics to physicists (Mathematical. Association and the Institute of Physies, 1944); and on sixth form examinations in mathematies (Cambridge Joint Advisory Committee for Mathematics, 1945). In suggesting an alternative syllabus to those in opera. tion at present, the first-named report makes the significant remark: "The whole syllabus is inspired by a desire to bring mathematics more closely in relation with the life and experience of the pupil". Herein lies the kernel of the question, and it is symptomatic of the dissatisfaction felt at the existing courses, which are largely dominated by the syllabuses of the examining authorities. With approximately four-fifths of the pupils now leaving secondary schools at school certificate level, the huge gap between examination mathematics and the essential needs of after-school life calls for some fundamental change. The need for a fresh approach to the mathematical curriculum has been ably dealt with by Mr. C. T. Lear Caton in his presidential address to the Midland Branch of the Mathematical Association (Math. Gaz., July 1945), and his advocacy "to replan the mathe. matics courses in all types of schools to fit in with the new educational structure and to contribute more effectively to the needs of the post-war world" sums up very concisely the case for immediate reform.

In Britain, the logical process of making necessary basic changes in established systems is traditionally slow; but the second great world war has shattered many of those systems so that progressive action is urgently imperative. The late Sir J. J. Thomson ("Recollections and Reflections") tells of a student who only learned to respect mathematics because of its application to billiards! This interesting case typifies the need for emphasizing the outward aspect of the subject and provides the clue to the guiding principle for reform. The problem, however, is far from easy, for it will obviously be dangerous to swing over to the other extreme by rejecting all that has no relation to what Sir Percy Nunn calls "the world of outer realities lying in time and space" ("The Teaching of Algebra"). On the other hand, there is little reason in placing a canopy of alleged difficulty round such a topic as infinite series when they hold the very key to the method of calculating tables, about which most students are so inquisitive. Indeed, the whole trend of any movement towards an intelligent reformation must be directed with much understanding, mature knowledge and an absolutely unbiased outlook.

\section{Quality Control in Business}

A serres of six articles by Mr. William B. Rice on quality control in business production and administration have been separately reprinted from Western Industry, the Journal of the American Statistical Association and the Accounting Review, and provides a useful introductory account for anyone interested in the application of statistical methods in business. Mr. Rice, who is the director of the Department of
Statistics and Reports of the Plomb Tool Company of Los Angeles, writes with first-hand experience of the methods he describes and drives home his points with a wealth of practical illustration. The first four of his articles deal with the control of quality of a manufactured product on fairly familiar lines-an expository presentation which should do much to arouse interest among manufacturers. In the remaining two he extends the technique to business administration and office accounting, showing, for example, how excessive overtime costs in a department of an engineering plant were tracked down and eliminated, and how administrative charges in a business were brought under control. This is quite a recent development of the subject, and provides an interesting illustration of the growth of scientific methods in the most ordinary commercial operations.

The statistical theory required in quality control is comparatively elementary; but the most striking successes have been obtained by introducing it into factory production processes. In some cases the methods amount to little more than a systematic sampling of the product and a graphical presentation of the results; and yet they appear to lead to the tracing of sources of trouble in the manufacturing process with an efficiency which astonishes nobody more than the men who have had years of experience on the job and are naturally inclined to think that they have nothing more to learn about it.

\section{Nutritive Values of War-time Foods}

DIETaRy surveys of the population which are being carried out by the Ministries of Food and Health have created a demand for food-tables giving, for raw foods, values for proteins, fats and carbohydrates and for the relatively small number of minerals and vitamins most likely to be deficient in human diet. Values for the composition of many foodstuffs con. sumed in war-time were not available in existing tables, and the differences between the values for war-time and peace-time foods are often very great. The Medical Research Council War Memorandum No. 14 now sets out "Nutritive Values of Wartime Foods" (Tables compiled for the Accessory Food Factors Committee. London: H.M. Stationery Office). Numerous analytical data, published and unpublished, have been considered in selecting the representative values in these tables. Many indiv. iduals have been consulted and have provided valuable data and advice. The values, including those for waste, are based for the most part on the results of direct analyses carried out during recent years in Britain. Such values were not always available, particularly for the vitamins, and it was necessary to make a selection from the values in the literature, distinguishing carefully those foods the composition of which had not been affected by the War. The losses during cooking are variable, affecting vitamin $C$ severely, vitamin $\mathbf{B}_{1}$ to a less extent and vitamin $\mathbf{A}$ probably still less. For processed foods, an allowance for loss of vitamins by destruction during cooking has been made in the tables.

\section{Control of Weeds by Spraying}

Loss in yield of cereal crops from competition with annual weeds is more serious than is generally realized, and gains of more than 50 per cent can often be expected as a result of correct spraying with a selective weed killer. Advisory Leaflet No. 315, Weed Control in Cereals, issued by the Ministry of Agriculture, 